\title{
KEPUASAN KERJA DAN PENINGKATAN PRESTASI KERJA
}

\author{
Oleh: \\ Muslikhah Dwihartanti \\ FISE UNY
}

\section{Abstrak}

Sebuah perusahaan tentu memiliki tujuan yang telah ditetapkan dan ingin diwujudkan melalui kegiatan operasional. Upaya untuk mewujudkan tujuan perusahaan tersebut sangat dipengaruhi oleh faktor lingkungan, baik fisik maupun nonfisik. Salah satu faktor nonfisik yang menjadi persoalan bagi perusahaan adalah masalah kepuasan kerja karyawan. Kepuasan kerja mempunyai arti penting bagi karyawan maupun perusahaan, terutama untuk menciptakan keadaan positif di lingkungan kerja perusahaan.

Sementara itu, prestasi kerja atau kinerja dalam organisasi merupakan jawaban dari berhasil atau tidaknya tujuan yang telah dirumuskan, karena ukuran terakhir keterhasilan departeman peronalia adalah prestasi kerja atau pelaksanaan kerja (performance) karyawan. Prestasi kerja perlu diberikan umpan balik sebagai pemacu untuk memperbaiki dan meningkatkan prestasi kerja pada masa yang akan datang.

Kepuasan kerja berhubungan dengan prestasi kerja karyawan, meskipun diantara keduanya sulit menentukan apa mempengaruhi yang mana. Hubungan prestasi dan kepuasan kerja menjadi suatu sistem yang berlanjut (continues). Dimana kondisi kepuasan dan ketidakpuasan kerja menjadi umpan balik atau feedback yang akan mempengaruhi prestasi kerja di waktu yang akan datang, untuk selanjutnya penghargaan dari prestasi akan memunculkan kepuasan maupun ketidakpuasan kerja.

Kata kunci: kepuasan kerja, prestasi kerja

\section{Pendahuluan}

Tidak dapat dipungkiri bahwa setiap orang dalam hidupnya akan selalu berusaha untuk memenuhi kebutuhannya. Dan kebutuhan setiap orang yang satu dengan lainnya sa- ngat mungkin berbeda. Hal ini sesuai dengan teori hierarki kebutuhan manusia dari Abraham Maslow (Indriyo Gitosudarmo, 2003 : 10), bahwa kebutuhan manusia memiliki struktur yang berjenjang, yaitu ke- 
butuhan sosiologik, kebutuhan rasa aman, kebutuhan sosial, kebutuhan harga diri dan kebutuhan sosialisasi diri. Kebutuhan yang paling mendasar dan setiap orang pasti selalu berusaha untuk memenuhinya adalah kebutuhan sosioiogik atau fisik, dimana kebutuhan ini sifatnya jasmaniah, pokok dan umum. Apabila kebutuhan fisik ini telah terpenuhi, orang akan beranjak pada kebutuhan jenjang berikutnya yaitu rasa aman. Demikian pula selanjutnya orang akan berusaha memenuhi kebutuhan yang lebih tinggi jenjangnya setelah kebutuhan dibawahnya terpenuhi.

Kebutuhan-kebutuhan tersebut berusaha untuk dipenuhi dengan cara bekerja. Dengan demikian ada orang yang bekerja karena ingin memenuhi kebutuhan pokok yang sifatnya fisik atau jasmaniah. Ada juga orang yang bekerja karena ingin bergaul atau berhubungan dengan banyak teman. Atau -ada yang bekerja karena ingin menunjukkan kepada orang lain bahwa ia mampu, sehingga orang lain bisa menghargainya, dan lain-lain.

Namun disamping orang bekeija untuk memenuhi kebutuhannya, dalam hal ini sebagai karyawan/ pegawai atau bagian dari manajemen personalia, maka organisasi atau perusahaan yang mempekerjakan karyawan, sebenarnya juga mempunyai tujuân dalam aktivitasnya, baik tujuan jangka pendek, jangka menengah, maupun tujuan jangka panjang. Oleh karena itu setiap perusahaan sebelum beroperasi terlebih dahulu telah merumuskan tujuan organisasi. Selanjutinya perusahaan melakukan aktivitas operasional dalam rangka mencapai tujuan yans ielah ditetapkan sebelumnya.

Dalam rangka mencapai tujuan organisasi, maka faktor lingkungan memberikan pengaruh yang cukup besar. Faktor lingkungan terdiri dari lingkungan fisik dan lingkungan non fisik. Lingkungan fisik terdiri dari sarana dan prasarana yang mendukung kelancaran karyawan dalam bekerja, seperti gedung, ruangan kantor, meja, kursi, fasilitas telepon, Air Conditioner ( $A C)$, komputer, dan lain-lain. Sedangkan lingkungan non fisik antara lain, situasi dan kondisi kerja, hubungan komunikasi dengan rekan kerja maupun pimpinan, adanya konflik dalam perusahaan/organisasi, kepuasan kerja para karyawan, semangat kerja, stress karyawan, dan lain-lain. Dengan demikian apabila lingkungan fisik maupun non fisik terganggu atau ada masalah, pasti akan mengganggu jalannya organisasi perusahaan.

\section{Kepuasan kerja}

Salah satu faktor yang berpengaruh terhadap kelancaran jalannya perusahaan adalah masalah kepuasan kerja dari para karyawannya. Mengapa kepuasan kerja karyawan bisa mempengaruni pencapaian tujuan perusahaan? Para 
karyawan yang tidak puas, mereka tidak akan bekerja dengan baik dan tidak produktif. Karyawan akan menganggap bahwa pekerjaannya cenderung membosankan dan tidak menarik. Akibatnya semangat kerja menjadi kendor dan tidak ulet, bekerja dengan terpaksa dan asal menghabiskan waktu. Efek selanjutnya adalah hasil kerja menjadi tidak maksimal. Sebaliknya, karyawan yang merasa puas akan bekerja dengan optimal dan bertanggung jawab terhadap pekerjaannya.

Apakah yang dimaksud dengan kepuasan kerja? Kepuasan kerja adalah perasaan mendukung atau tidak mendukung yang dialami karyawan dalam pekerjaannya. Kepuasan kerja adalah kondisi emosional karyawan dengan adanya kesesuaian atau ketidaksesuaian antara harapan dan kenyataan. Apabila harapan karyawan sesuai dengan kenyataan, maka akan muncul kepuasan dari karyawan. Sebaliknya, apabila harapan karyawan tidak sesuai dengan kenyataan, maka akan muncul ketidakpuasan karyawan. Menurut Hani Handoko (2001: 193), kepuasan kerja adalah keadaan emosional yang menyenangkan atau tidak menyenangkan dengan mana para karyawan memandang pekerjaan mereka. Kepuasan kerja mencerminkan perasaan seseorang terhadap pekerjaannya. Kepuasan kerja seorang karyawan biasanya akan terlihat dari sikap positif karyawan ter- sebut dalam menghadapi segala sesuatu di lingkungan kerjanya.

Kepuasan kerja ternyata juga dapat mempengaruhi tingkat absentsi, perputaran tenaga kerja, semangat kerja, keluhan-keluhan, dan lain-lain, meskipun kepuasan kerja bukan satu-satunya faktor yang mempengaruhi. Apabila kepuasan kerja karyawan rendah, karyawan lebih mudah meninggalkan perusahaan dan pindah ke perusahaan lain. Demikian juga dengan absentsi. Karyawan cenderung lebih sering absen ketika kepuasan kerjanya rendah karena tidak ada sesuatu yang diharapkan dari perusahaan. Dengan kepuasan kerja yang tinggi, perusahaan dapat mengharapkan perputaran karyawan dan absensi yang menurun. Seperti dikatakan oleh Gary Dessler, karyawan yang mendapatkan kepuasan kerja biasanya mempunyai catatan kehadiran dan perputaran yang lebih baik, kurang aktif dalam kegiatan serikat kary $3 w a n$, dan (kadangkadang) berprestasi kerja lebih baik daripada karyawan yang tidak memperoleh kepuasan kerja (1982 : 364). Demikian juiga yang dikatakan oleh Faustino Cardoso Gomes (1997 : 178), bahwa kepuasan kerja dari pegawai itu sendiri mungkin mempengaruhi kehadirannya pada kerja, dan keinginan untuk ganti pekerjaan juga bisa mempengaruhi kesediaan untuk bekerja. Oleh karena itu kepuasan kerja 
karyawan harus terus dipantau, sehingga dapat diketahui ada atau tidaknya permasalahan dari karyawan.

\section{Faktor-Faktor yang Mempengaruhi Kepuasan Kerja}

Kepuasan kerja karyawan dapat dipengaruhi oleh faktor-faktor tertentu, baik dari dalam diri maupun dari luar. Adapun beberapa hal yang mempengaruhi kepuasan kerja karyawan menurut Schemerhorn (wikipedia) adalah :

1. Pekerjaan itu sendiri (work it self)

Setiap pekerjaan memerlukan cara penyelesaian tersendiri. Tingkat kerumitan suatu pekerjaan serta perasaan karyawan bahwa ia memiliki keahlian dan kemampuan yang sesuai dengan pekerjaan yang menjadi tanggung jawabnya sehingga mampu menyelesaikan pekerjaan dengan baik, menjadi salah satu alasan untuk meningkatkan kepuasan atau justru menurunkan kepuasan karyawan. Apabila seorang karyawan merasa bahwa pekerjaan yang dihadapi sulit, sementara ia merasa tidak memiliki kemampuan untuk menyelesaikannya, maka hal tersebut cenderung akan menurunkan kepuasan karyawan. Sebaliknya, apabila karyawan menganggap bahwa pekerjaannya mudah dan didukung kemampuan atau keahlian yang dimiliki sehingga menyebabkan ia mampu menyelesaikan pekerjaannya, maka kemungkinan besar karyawan tersebut akan merasa puas. $\mathrm{Na}$ mun demikian bagi sebagian orang, pekerjaan yang rumit dan menantang justru disukai karena dianggap menguji kemampuan mereka. Dan kemampuan menyelesaikan pekerjaan tersebut akan memunculkan kepuasan. Yang harus diketahui adalah bahwa pekerjaan yang terlalu mudah cenderung menimbulkan kebosanan karena tidak ada tantangan. Tetapi pekerjaan yang terlalu rumit dan susah juga akan menimbulkan stress dan frustasi. Pada posisi dimana dalam pekerjaan ada tantangan yang tingkatannya sedang, kemungkinan karyawan akan merasa nyaman dan puas.

2. Penyelia (supervision) atau atasan

Sikap atasan sangat menentukan dan mempengaruhi kepuasan karyawan. Seorang atasan yang baik akan menghargai bawahan dan pekerjaan bawahannya. Apabila bawahan merasa diperlakukan sebagai manusia, dibimbing dan dihormati, meskipun kedudukannya lebih rendah, maka ia akan bekerja dengan giat dan cenderung merasa puas. Sebaliknya, bawahan yang merasa ditekan oleh atasannya, tidak dihargai dan merasa dipaksa, justru membuat pekerjaannya semakin kacau dan tidak akan memberikan hasil yang maksimal. Hal ini berakibat karyawan tidak merasa puas dengan pekerjaannya. 
3. Rekan kerja (workers)

Sama dengan atasan, rekan kerja merupakan partner dalam menyelesaikan suatu pekerjaan. Dalam keseharian, seorang karyawan tidak bisa menyelesaikan pekerjaan tanpa berhubungan dengan rekan sesama pekerja. Apabila seorang karyawan memiliki hubungan yang baik dengan rekan kerjanya, maka ia akan merasa nyaman bekerja dan hal ini memunculkan kepuasan bagi karyawan tersebut. Sebaliknya, apabila karyawan memiliki hubungan yang kurang harmonis dengan rekan kerjanya, ia tidak akan merasa nyaman dengan pckerjaannya yang berakibat pada ketidakpuasan kerja.

\section{Promosi}

Promosi merupakan jalan untuk meningkatkan karir seorang karyawan. Setiap perusahaan memberlakukan kebijakan promosi atau naik jabatan/kedudukan yang berbeda dengan perusahaan lainnya. Apabila setelah mencapai suatu waktu atau telah menyelesaikan pekerjaan dengan baik, kemudian karyawan tersebut memperoleh promosi jabatan, dapat dipastikan ia akan merasa puas dalam kerjanya. Sebaliknya, apabila karyawan tersebut telah lama bekerja tetapi tidak ada penghargaan berupa kesempatan peningkatan jenjang karir, karyawan akan merasa bahwa apa yang ia lakukan tidak dihargai dan hal ini akan menyebabkan ketidakpuasaii káryawan tersebut.
5. Gaji

Gaji merupakan kompensasi yang diberikan oleh perusahaan kepada karyawan. Antara gaji dan kualitas kerja saling berhubungan dan sulit menentukan "apakah gaji akan mempengaruhi kualitas kerja ataukah kualitas kerja yang menentukan besaran gaji atau upah". $\mathrm{Na}$ mun demikian, gaji atau kompensasi yang diterima oleh seorang karyawan pasti akan berpengaruh pada kepuasan atau ketidakpuasan karyawan tersebut dalam bekerja. Seandainya karyawan memperoleh gaji yang cukup atau memadai, sangat mungkin karyawan tersebut memperoleh kepuasan sehingga membuat lebih giat bekerja. Sebaliknya, minimnya gaji yang diterima sering menimbulkan ketidakpuasan karyawan dan cenderung menurunkan semangat kerja sehingga mengganggu jalannya perusahaan. Oleh karena itu faktor gaji atau kompensasi sangat penting dan harus dipikirkan besarannya dengan hati-hati.

Beberapa faktor yang mempengaruhi kepuasan kerja yang telah disebutkan diatas, merupakan faktor yang berasal dari luar diri karyawan. Dalam hal ini Top management bisa mengkoridisikan, mengusahakan agar karyawan memperoleh kepuasan kerja yang tinggi dan mengurangi ketidakpuasan. Misalnya dengan cara memperhatikan masalah pengupahan atau gaji, se- 
lalu memberikan promosi pada karyawan yang secara kualitas mampu, menciptakan suasana kerja yang nyaman, berusaha mendekatkan diri diantara semua level pekerjaan, dan lain-lain.

Selain itu, kepuasan kerja dapat dicapai dengan cara-cara tertentu, yang berasal dari dalam diri karyawan. Artinya, karyawan memiliki niat dan dorongan dari dalam diri untuk mencapai kepuasan kerja. Beberapa cara mencapai kepuasan kerja tersebut antara lain:

1. Memulai dengan sasaran akhir

Dengan menentukan sasaran akhir, maka karyawan telah menetapkan suatu tujuan akhir yang ingin dicapai. Dan hal ini dapat dijadikan sebagai pedoman sekaligus pemberi semangat dalam bekerja. Selanjutnya untuk mencapai sasaran tersebut ditentukan cara atau strateg! yang akan dilakukan.

2. Mencintai pekerjaan

Cinta kepada pekerjaan akan menjadi pendorong atau pemacu semangat untuk melakukan pekerjaan dengan baik dan sempurna. Sebaliknya, ketidaksukaan terhadap pekerjaan cenderung membuat karyawan malas untuk menyelesaikan pekerjaan dengan baik.

3. Mengerjakan sampai tuntas

Setiap karyawan dibebani dengan pekerjaan yang menuntut untuk diselesaikan. Ketika karyawan bekerja atau menyelesaikan pekerjaan sampai ke akarnya, tidak sekedar selesai tapi juga sampai tuntas, maka hal itu akan memunculkan kepuasan batin tersendiri. Sebalikriya, suatu pekerjaan yang tidak bisa selesai dengan baik biasanya memunculkan kekhawatiran. Apakah dimarahi atasan, dianggap tidak mampu, ketakutan mendapatkan sanksi, dan lain-lain.

4. Fokus pada keunggulan tertentu

Setiap karyawan memiliki kelemahan dan kelebihan tertentu yang berbeda. Agar tercapai kepuasan, maka perlu ditetapkan keunggulan yang dimiliki agar dapat memfokuskan perhatian pada keunggulan tersebut dan berusaha melakukan yang terbaik.

\section{Prestasi kerja}

Prestasi kerja sering disebut orang dengan kata kinerja atau hasil kerja. Prestasi kerja atau kinerja dalam organisasi merupakan jawaban dari berhasil atau tidaknya tujuan yang telah dirumuskan. T. Hani Handoko (2001) mengatakan bahwa:...ukuran terakhir keberhasilan departemen personalia adalah prestasi kerja atau pelaksanaan kerja (performance) karyawan. Dengan demikian prestasi kerja digunakan untuk mengetahui tingkat pencapaian hasil, sesuai dengan visi dan tujuan yang ditetapkan.

Kinerja atau prestasi kerja menurut Anwar Prabu Mangkunegara (wikipedia, kinerja) adalah ha- 
sil secara kualitas dan kuantitas yang dicapai oleh seseorang pegawai dalam melaksanakan tugasnya sesuai dengan tanggung jawab yang diberikan kepadanya. Kinerja merupakan kualitas dan kuantitas dari suatu hasil kerja (output) individu maupun kelompok dalam suatu aktivitas tertentu yang diakibatkan oleh kemampuan alami atau kemampuan yang diperoleh dari proses belajar serta keinginan untuk berprestasi.

Hasil dari kerja yang merupakan prestasi kerja karyawan, memerlukan adanya umpan balik sesuai prestasi dan upaya-upaya yang telah dicapai. Hal ini penting agar karyawan tetap berusaha dan bahkan semakin meningkatkan prestasinya, ataupun agar apabila terjadi hasil prestasi yang tidak memuaskan dapat dicari penyebab serta solusinya. Untuk itu diperlukan penilaian crestasi kerja sebagai alat untuk mengukur prestasi yang telah dicapai karyawan.

Menurut T. Hani Handoko (2001 : 135) penilaian prestasi kerja adalah proses melalui mana organisasi-organisasi mengevaluasi atau menilai prestasi kerja karyawan. Kegiatan ini dapat memperbaiki keputusan-keputusan personalia dan memberikan umpan balik kepada para karyawan tentang pelaksanaan kerja mereka. Manfaat penilaian prestasi kerja menurut Hani Handoko adalah sebagai berikut:
1. Perbaikan prestasi kerja Umpan balik pelaksanaan kerja memungkinkan karyawan untuk membetulkan dan memperbaiki kegiatan-kegiatan dalam rangka memperbaiki prestasi kerja.

2. Penyesuaian-penyesuaian kompensasi

Evaluasi prestasi kerja membantu top management dalam menentukan kenaikan upah, pemberian bonus, dan kompensasi-kompensasi yang lainnya.

3. Keputusan-keputusan penempatan

Promosi maupun transfer biasanya didasarkan pada prestasi kerja yang telah dicapai sebelumnya. Promosi merupakan salah satu bentuk penghargaan terhadap prestasi kerja.

4. Kebutuhan-kebutuhan latihan dan pengembangan

Prestasi kerja yang kurang baik bisa jadi menunjukkan kebutuhan latihan atau perlunya dilaksanakan latihan bagi karyawan. Sebaliknya, prestasi kerja yang baik bisa jadi mencerminkan potensi yang perlu untuk dikembangkan.

5. Perencanaan dan pengembangan karir

Umpan balik prestasi mengarahkan keputusan-keputusan karier, yaitu tentang jalur karier tertentu yang harus diteliti.

6. Penyimpangan-penyimpangan proses staffing 
Prestasi kerja mencerminkan kekuatan atau kelemahan prosedur staffing departemen personalia.

7. Ketidakakuratan informasional

Prestasi kerja yang tidak baik mungkin menunjukkan kesalahan-kesalahan informasi analisis jabatan, rencana SDM dan lain-lain. karena informasi yang tidak akurat sangat mungkin menjadikan keputusan yang diambil juga salah.

8. Kesalahan-kesaiahan desain pekerjaan.

Prestasi kerja yang jeiek mungkin merupakan suatu tanda kesalahan dalam desain pekerjaan. Dan penilaian prestasi diharapkan dapat membantu memperbaiki kesalahan tersebut.

9. Kesempatan kerja yang adil

Penilaian prestasi kerja akan dapat menjamin keputusan penempatan kerja yang adil dan tidak memihak atau pilih kasih.

10. Tantangan-tantangan eksternal Kadang-kadang prestasi kerja dipengaruhi oleh faktor eksternal, seperti keluarga, kesehatan, keadaan finansial, serta masalah pribadi yang lainnya. Penilaian prestasi kerja mungkin dapat membantu mengatasi tantangan tersebut:

\section{Hubungan Kepuasan Kerja dan Prestasi Keria}

Adakan hubungan antara kepuasan kerja dan pencapaian prestasi karyawan ? Kebanyakan orang sering menganggap bahwa apabila karyawan memperoleh kepuasan kerja yang tinggi, mereka akan melaksanakan pekerjaan dengan baik ataupun memperoleh prestasi yang tinggi pula. Ternyata kenyataannya tidak selalu demikian. Pada suatu saat bisa saja terjadi karyawan mencapai tingkat kepuasan tinggi, tapi hal itu tidak bisa menjadikan karyawan tersebut untuk produktif. Meskipun demikian, kepuasan kerja tetap diperlukan untuk memelihara motivasi karyawan agar bekerja lebih giat dan lebih baik lagi. Oleh karena itu kepuasan ataupun ketidakpuasan karyawan terhadap pekerjaannya, tetap berhubungan dengan prestasi kerja karyawan tersebut, dimana ujungnya akan berpengaruh terhadap pencapaian tujuan perusahaan.

Pertanyaan selanjutnya adalah apakah kepuasan kerja akan mempengaruhi prestasi kerja karyawan atau sebaliknya, prestasi kerja akan miemunculkan kepuasan kerja dari karyawannya. Mieilurut T. Hani Handoko (2001 : 195), hubungan prestasi dan kepuasan kerja menjadi suatu sistem yang berlaniut (continues). Seperti ditunjukkan pada gambar berikut: 
Umpan balik

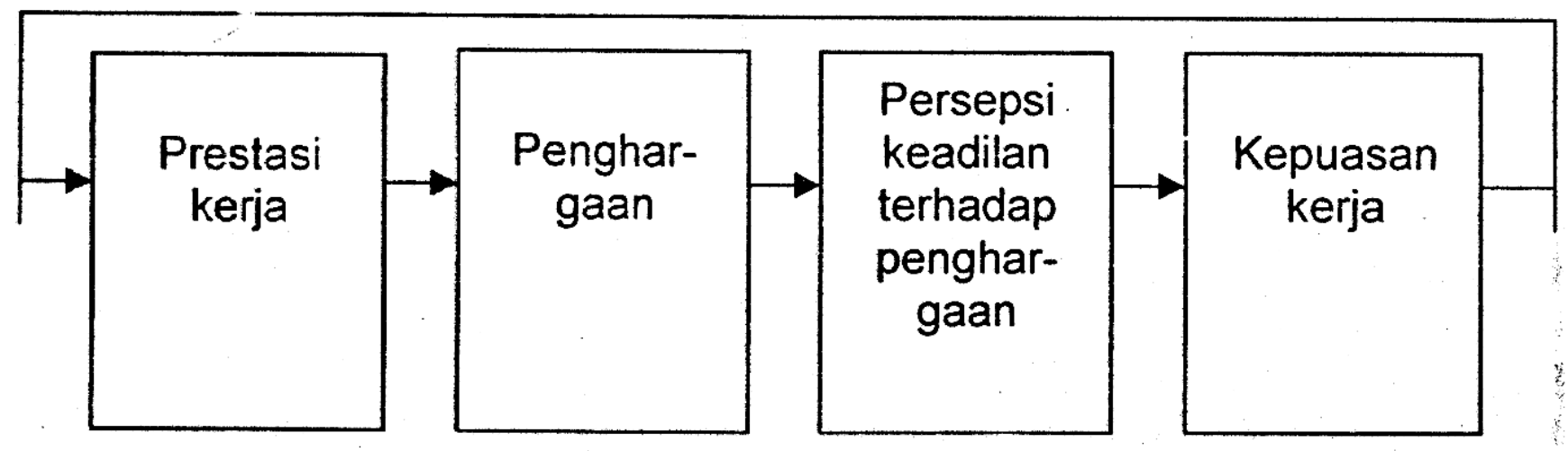

Gambar. 1.

Hubungan antara Prestasi dan Kepuasan Kerja

Seperti ditunjukkan dalam gambar, prestasi kerja yang lebih baik mengakibatkan penghargaan yang lebih tinggi. Bila penghargaan tersebut dirasakan adil dan memadai, maka kepuasan kerja karyawan akan meningkat karena mereka menerima penghargaan dalam proporsi yang sesuai dengan prestasi kerja mereka. Di lain pihak, bila penghargaan dipandang tidak mencukupi untuk suatu tingkat prestasi kerja karyawan, ketidakpuasan kerja cenderung terjadi. Kondisi kepuasan dan ketidakpuasan kerja selanjutnya menjadi umpan balik atau feedback yang akan mempengaruhi prestasi kerja di waktu yang akan datang.

\section{Penutup}

Upaya untuk mencapai tujuan perusahaan yang telah ditetapkan memang bukan hal yang mudah. Faktor sumber daya manusia menjadi salah satu hal yang perlu diperhatikan dengan serius. Setiap karyawan memiliki karakteristik, sifat, kebutuhan dan tujuan yang berbeda dengan karyawan yang lain sehingga menbuat top management harus melakukan perencanaan SDM yang matang atas karyawan-karyawan tersebut.

Apabila perusahaan mengharapkan organisasinya dapat berhasil dan terus berkembang, maka masalah kepuasan kerja karyawan harus betui-betul diperhatikan. Hal ini penting mengingat karyawan merupakan pelaksana kegiatan operasional perusahaan. Kepuasan ataupun ketidakpuasan kerja karyawan akan ikut menentukan pencapaian prestasi kerja pada waktu yang akan datang. Paling tidak, kepuasan kerja karyawan penting sebagai pembangun motivasi bagi karyawan untuk bekerja lebih baik. Sementara itu prestasi kerja atau kinerja pada akhirnya berfungsi untuk mengukur keberhasilan manajemen personalia.

Dengan demikian setiap karyawan diupayakan memiliki ki- 
nerja yang tinggi yang ditandai oleh beberapa karakteristik, antara lain: a). berorientasi pada prestasi, artinya karyawan tersebut memiliki semangat kerja yang tinggi, selalu berusaha untuk bekerja dan menghasilkan karya yang terbaik, b). memiliki percaya diri, artinya percaya pada kemampuan diri, bisa mengukur kelebihan dan kelemahannya, c). mampu mengendalikan diri, tidak mudah menyerah dan terlarut dalan situasi dan kondisi yang dapat membawa kearah yang negatif, d). memiliki kompetensi, dengan berpegang pada prinsip yang kuat dan memiliki tujuan yang jelas.

\section{Daftar Pustaka}

Faustino Cardoso Gomes. 1997. Manajemen Sumber Daya Manusia. Yogyakarta: Andi Offset.

Gary Dessler. 1982. Organization and Management. Virginia: Reston Publishing Company, inc. Indriyo Gitosudarmo. 2003. Pengantar Bisnis. Yogyakarta: BPFEYogyakarta.
T. Hani Handoko. 2001. Manajemen Personalia dan Sumber Daya Manusia. Yogyakarta: BPFEYogyakarta.

http://id.wikipedia.org/wiki/kepuasan kerja.

http://id.wikipedia.org/wiki/kineria.

\section{Biodata Penulis}

Muslikhah Dwihartanti, SIP., adalah salah satu staf pengajar pada Program Studi Pendidikan Aáministrasi Perkantoran Fakultas IImu Sosial dan Ekonomi Universitas Negeri Yogyakarta. Menamatkan Studi S1 pada/Fakultas IImu Sosiai dan IImu Politik Universitas Gadjah Mada. 